\title{
PEMANFAATAN PRODUK OLAHAN URINE SAPI MENGGUNAAKAN SISTEM AERASI SEBAGAI PUPUK ORGANIK CAIR (POC) di DESA SEPAKEK, KECAMATAN PRINGGARATA, KABUPATEN LOMBOK TENGAH
}

Ninda Septiani1, Heti Sufiani2, Hudian Yusfil Hazmi3, Lalu Rezfiqhi Martadinata4, Made Widyanita Dewi Santi5, Nurhidayati6, Jayeng Tinon Irfani7, Lalu Muh. Yudit Narapratama8, Devi Marlinda9*, Ni Wayan Mega Whidya Sridani 10

\author{
1,2, 4, 5, 6, 7, 8, 9, 10 Mahasiswa Universitas Universitas Mataram \\ ${ }_{3}$ Program Studi PGSD FKIP Universitas Mataram \\ ${ }^{*}$ Co-Author : Marlinda99devi@gmail.com
}

\begin{abstract}
ABSTRAK. Pupuk organik dapat berbentuk padat atau cair, pupuk ini dapat diperoleh dari alam dan ketersediannya terus meningkat. Pupuk organik dari limbah urine sapi dapat mencegah ketergantungan petani terhadap pupuk kimia. Pupuk organik cair (POC) urine sapi mempunyai manfaat untuk menyuburkan tanaman, untuk menjaga stabilitas unsur hara dalam tanah, untuk mengurangi dampak sampah organik di lingkungan sekitar, membantu. Tujuan dari pemanfaatan produk olahan pupuk organik cair (POC) urine sapi adalah untuk memberikan kesadaran arti penting pengolahan limbah menjadi pupuk organik cair. Metode yang digunakan yaitu metode fermentasi dan metode dengan sistem aerasi. Hasil dari pegujian lab ketiga sampel yang dibuat yaitu sampel 2 yang memiliki nilai $\mathrm{N}$ dan $\mathrm{NH}_{3}$ yang sesuai dengan kebutuhan tanaman dengan kandungan $\mathrm{N}(0,14 \%)$ dan kandungan (NH3 153 (mg/L)).
\end{abstract}

Kata Kunci: Urine sapi, fermentasi, sistem aerasi.

ABSTRACT. Organic fertilizer can be shaped solid or liquid, this fertilizer can be obtained from natural and supplementary continue to increase. Organic fertilizer from cow urine waste can prevent farmers 'dependence on chemical fertilizers. Liquid Organic Fertilizer (POC) of cow urine has the benefit to fertilize crops, to maintain the stability of the nutrients in the soil, to reduce the impact of organic waste in the environment, help. The purpose of the utilization of processed products of liquid organic fertilizer (POC) of cow urine is to give awareness of the meaning of waste treatment into liquid organic fertilizer. Method used is method of fermentation and method with aeration system. Results of the third Pegujian Lab samples made i.e. 2 samples that had a value $N$ and $N H 3$ that matched the plant with the content of $N(0,14 \%)$ and content $(\mathrm{NH3} 153(\mathrm{mg} / \mathrm{L}))$..

Keyword: Cow Urine, fermentation, aeration system

\section{PENDAHULUAN}

Pupuk adalah suatu bahan yang dapat ditambahkan pada media tanam untuk mencukupi kebutuhan tanaman sehingga tumbuhan yang ditanam mampu tumbuh dengan baik. Pupuk dibagi menjadi dua jenis yaitu pupuk anorganik dan organik. Pupuk anorganik merupakan pupuk buatan yang terbuat dari bahan kimia yang diproduksi secara komersil sedangkan pupuk organik yaitu pupuk yang terbuat penguraian bahan alami yang ada di alam baik dari sampah maupun bahan sisa yang dikeluarkan oleh mahluk hidup. Kedua jenis pupuk memiliki fungsi yang sama yaitu membantu 
menyuburkan tamanan karena mengandung unsur hara yang dibutuhkan tumbuhan. Dari kedua jenis pupuk, pupuk organik merupakan pupuk yang ramah lingkungan karena pupuk organik dapat mengatasi akibat negatif dari penggunaan pupuk anorganik dengan dosis tinggi secara terus menerus.

Pupuk organik dapat berbentuk padat atau cair, pupuk ini dapat diperoleh dari alam dan ketersediannya terus meningkat. Pupuk organik mengandung bahan organik serta berfungsi untuk memperbaiki kesuburan kimia, fisik dan biologis tanah Komposisi fisika, kimia, dan biologi pupuk organik sangat bervariasi dan manfaatnya bagi tanaman tidak secara langsung terlihat, serta respon tanaman relatif lambat. Pupuk organik diperlukan dalam dosis yang relatif tinggi (minimal $2 \mathrm{t}$ ha-1 MT-1) (Pranata, 2004 dalam Siburian, 2016). Pupuk organik di pasaran telah berkembang cukup luas, masyarakat lebih beralih kepada pupuk organik karena disamping harga yang lebih ekonomis juga sangat ramah lingkungan. Pupuk organik biasanya dibuat dalam bentuk padat yang diperoleh dari kotoran ternak. Penggunaanya dapat diberikan secara langsung pada media tanam layaknya pupuk yang lainnya. Selain dari kotoran ternak, urine ternak juga dapat dimanfaatkan menjadi pupuk organik cair. Menurut Putri (2017) bahwa pupuk organik cair selain dapat memperbaiki sifat fisik, kimia dan biologi tanah, membantu produksi tanaman, mengurangi penggunaan pupuk anorganik dan sebagai alternative pengganti pupuk kandang. Salah satu urine ternak yang dapat dijadikan pupuk organik cair adalah limbah dari urine sapi.

Pupuk organik dari limbah urine sapi dapat mencegah ketergantungan petani terhadap pupuk kimia. Pupuk organik cair (POC) urine sapi mempunyai manfaat untuk menyuburkan tanaman, untuk menjaga stabilitas unsur hara dalam tanah, untuk mengurangi dampak sampah organik di lingkungan sekitar, untuk membantu revitalisasi produktivitas tanah dan untuk meningkatkan kualitas produk. Keunggulan penggunaan pupuk organik cair (POC) urine sapi yaitu volume penggunaan lebih hemat dibanding pupuk organik padat serta aplikasi pupuk organik cair (POC) mudah diberikan melalui penyemprotan, serta dengan proses akan dapat ditingkatkan kandungan haranya (unsur nitrogen) (Warasfarm, 2013 dalam Rohani 2016). Pupuk organik cair (POC) urine sapi selain memiliki keunggulan juga memiliki kekurangan. Salah satu kekurangannya yaitu memiliki bau yang menyengat karena adanya kandungan amoniak. Amoniak dapat dihilangkan dengan beberapa metode yaitu dengan metode fermentasi atau dengan metode aerasi.

Limbah urine sapi yang telah difermentasi dapat meningkatkan produksi tanaman sayuran. Urine sapi mengandung unsur $\mathrm{N}, \mathrm{P}, \mathrm{K}$ dan Ca yang cukup tinggi dan dapat meningkatkan ketahanan tanaman terhadap serangan penyakit (Phrimantoro, 2002 dalam Rizki, 2014). Dari analisis laboratorium terhadap sifat urin sapi sebelum dan sesudah fermentasi terdapat perbedaan, sebelum fermentasi $\mathrm{pH}(7,2), \mathrm{N}(1,1 \%), \mathrm{P}(0,5 \%), \mathrm{K}(1,5 \%)$, $\mathrm{Ca}(1,1 \%)$ warna kuning, dan bau menyengat, sesudah fermentasi $\mathrm{pH}(8,7), \mathrm{N}(2,7 \%), \mathrm{P}(2,4 \%) \mathrm{K}(3,8 \%)$, Ca $(5,8 \%)$ warna hitam dan bau berkurang (Affandi. 2008 dalam Rizki, 2014). Anty (1980 dalam Rizki, 2014) melaporkan bahwa urin sapi mengandung nitrogen dan zat perangsang tumbuh alami dari golongan IAA, giberelin (GA) dan sitokinin. Nitrogen dalam urin sapi berbentuk senyawa amoniak sehingga memberikan pengaruh negatif terhadap pertumbuhan vegetatif tanaman karena suhunya yang tinggi. Suhu ini dapat diturunkan dengan menurunkan kadar amoniak dalam urine sapi dengan cara fermentasi, baik menggunakan bakteri pengurai atau dengan cara menyimpan urine tersebut. Selain menggunakan metode fermentasi, metode yang dapat digunakan yaitu metode dengan sistem aerasi. 
Proses pemanfaatan urine sapi menggunakan metode sistem aerasi yaitu meberikan oksigen menggunakan aerator kedalam urine sapi agar kandungan amoniak yang ada pada urine dapat menguap. Menurut wahyono (2011) dalam Rasyid (2017) bahwa sistem aerasi yang baik dapat didukung dengan pemanfaatan porositas bahan, terowongan angin dibawah tumpukan, dan pembalikan tumpukan yang reguler. Ketersediaan nutrien dapat dicukupi dengan mengatur rasio karbon dan nitrogen ( $\mathrm{C} / \mathrm{N}$ ratio). Aerasi diperlukan untuk menjamin kebutuhan oksigen baik dari organisme budidaya maupun biomas bakteri. Selain berperan dalam penyediaan oksigen, aerasi juga berfungsi untuk mengaduk (mixing) agar suspensi tidak mengendap. Penelitian menggunakan aerasi sebagai penambah udara atau oksigen diharapkan dapat mengetahui perbedaan kandungan unsur hara pupuk cair yang diareasi. Selanjutnya hasil penelitian dapat dimanfaatkan sebagai acuan dalam meningkatkan kandungan unsur hara pupuk cair melalui penambahan udara serta untuk menghilangkan kadar amoniak yang tinggi (Ekasari, 2009 dalam Rasyid, 2017).

Berdasarkan hasil survey yang telah dilakukan dari seluruh potensi yang ada di desa Sepakek maka, secara umum yang dapat dimanfaatkan yaitu pada sektor peternakan dan pertanian. Sektor peternakan maupun pertanian merupakan sumber mata pencaharian masyarakat lokal di desa Sepakek dengan tingkat penyerapan tenaga kerja tertinggi. Salah satu potensi yang dapat dikembangkan dari sektor peternakan dan pertanian yaitu potensi limbah urine sapi yang dapat dijadikan sebagai pupuk organik cair (POC) untuk meningkatkan kesuburan tanaman. Pada umumnya limbah urine sapi dibuang secara percuma oleh para peternak. Hal ini disebabkan oleh kurangnya pengetahuan dari para peternak untuk memanfaatkan potensi limbah tersebut. Potensi ini didukung oleh banyaknya peternak sapi dan kandang kolektif sehingga ketersedian limbah terus meningkat. Disamping itu, limbah urine sapi juga memiliki nilai jual yang tinggi. Pengembangan produk olahan urine sapi telah berkembang luas dipasaran, masyarakat lebih memilih menggunakan pupuk organik karena harga yang lebih ekonimis dibandingkan pupuk anorganik. Dengan adanya hal tersebut, hal yang dapat dilakukan untuk mengatasi permasalahan pada sektor peternakan dan pertanian yaitu mengembangkan potensi desa yang didukung oleh keterlibatan masyarakat desa untuk terus mengembangkan limbah urine sapi menjadi pupuk cair organik.

Oleh karena itu, limbah urine sapi yang dapat dijadikan pupuk organik cair perlu untuk dikembangkan, mengingat potensi desa dan ketersediannya terus meningkat serta mengurangi limbah peternakan yang apabila berlebihan tanpa adanya pemanfaatan dapat merusak lingkungan sekitar.

Tujuan dari pemanfaatan produk olahan pupuk organik cair (POC) urine sapi adalah untuk memberikan kesadaran masyarakat bagaimana arti penting pemanfaatan pengolahan limbah urine sapi menjadi pupuk organik cair yang memiliki nilai jual.

\section{METODE}

Metode yang digunakan dalam pembuatan produk olahan urine sapi yaitu metode fermentasi dan metode dengan sistem aerasi. Pembuatan produk olahan dilaksanakan di dusun Nyangget, desa Sepakek kecamatan Pringgarata, kabupaten Lombok Tengah pada bulan Desember 2019 sampai bulan Februari 2020. Pengujian unsur hara dalam fermentasi urine sapi dilakukan di Laboratorium IImu Nutrisi dan Makanan Ternak, Fakultas Petenakan, Universitas Mataram. Adapun alat-alat yang digunakan yaitu 3 buah tong dengan volume 50 liter, aerator, selang kecil, toples kecil, 
lem tembak sedangkan bahan-bahan yang digunakan antara lain yaitu urine sapi, bio decomposer (EM4), molases, air kelapa, gula merah, lengkuas

\section{Fermentasi Urine Sapi}

Urine sapi di tampung menggunakan 3 tong yang berbeda dan ditambahkan bahan tambahan di masing-masing tong penampungan. Proses pembuatan urine sapi diantaranya yaitu disiapkan 3 tong dengan volume 50 liter sebagai tempat fermentasi. Pada tong pertama ditambahkan bio decomposer (EM4) dan lengkuas sedangkan pada tong kedua dittambahkan molasses, bio decomposer (EM4) dan air kelapa sedangkan pada tong ketiga ditambahkan gula merah, decomposer (EM4) dan air kelapa. Perbandingan antara urine dan bahan tambahan yaitu 50:1 yang artinya untuk 50 liter urine sapi dapat ditambahkan bahan tambahan tersebut dapat ditambahkan 1 $\mathrm{kg}$ atau 1 liter bahan tambahan yang berbeda. Setelah bahan-bahan tersebut ditambahkan pada masing-masing tong kemudian ketiga tong tersebt tong yang berisi urine sapi dan bahan tambahan lainnya ditutup rapat dan difermentasikan selama 15 hari.

\section{Penguraian Amoniak}

Setelah proses fermentasi selama 15 hari, dilakukan penghilangan amoniak atau bau menyengat yang ada pada urine sapi tersebut menggunakan sistem aerasi. Sistem ini menggunakan aerator sebagai penyuplai oksigen pada tong penampungan urine sapi. Sistem ini memanfaatkan oksigen sebagai penghilang gas amoniak melalui penguapan. Pada proses ini aerartor akan disambungkan menggunakan selang kecil dan akan terjadi proses pengadukan. Aerator dapat dinyalakan selama 6 jam perhari, sehingga waktu yang dibutukan yaitu 6 hari untuk menghilang gas amoniak tersebut.

\section{HASIL DAN PEMBAHASAN}

Pupuk organik cair sapi yang dibuat terdiri dari tiga sampel dengan bahan-bahan tambahan yang berbeda. Tujuannya adalah untuk mengetahui perbedaan kualitas baik dari kandungan senyawa yang terkandung dan kadar amoniak setelah penambahan bahan serta mengetahui pupuk organik cair sapi. sampel yang pertama menggunakan bahan yaitu urine sapi, air beras, air kelapa, molases. Pupuk organik cair (POC) sapi, sampel kedua menggunakan bahan yaitu urine sapi, gula merah, air kelapa dan POC sapi sampel tiga menggunakan bahan urine sapi molases, air kelapa. Sampel ketiga tersebut menggunakan waktu fermentasi yang berbeda. Ketiga sampel tersebut menggunakan sistem aerasi. Sistem aerasi adalah proses pembuatan pupuk yang membutuhkan udara dimana bakterinya membutuhkan oksigen. Sistem aerasi ini dilakukan supaya senyawa amoniak yang terkandung tidak tinggi.

Pada proses fermentasi, waktu yang dibutuhkan selama 15 hari, hal tersebut karena merupakan waktu yang sesuai untuk unsur hara yang ada dalam urine mengurai secara sempurna. Fermentasi yang terlalu lama juga akan mempengaruhi kualitas pupuk cair yang dihasillkan. Menurut Walunguru (2010) dalam Rohani (2016) bahwa kualitas pupuk (baik padat maupun cair) dapat menurun selama penyimpanan. Selama penyimpanan, meskipun telah dilakukan dengan baik unsur hara dapat menguap dan atau menjadi tidak tersedia sehingga semakin lama waktu simpan maka dapat menyebabkan kualitas pupuk makin menurun. Pupuk organik cair dari urine sapi adalah pupuk yang mudah menguap, bersama dengan penguapan tersebut $\mathrm{N}$ dan $\mathrm{S}$ hilang dalam bentuk gas. Unsur $\mathrm{N}$ merupakan unsur yang kehilangan terbesarnya disebabkan penguapan dan denitrifikasi. 
Dari ketiga sampel yang dibuat, ketiga sampel tersebut diuji lab. Pengujian sampel dilakukan di lab peternakan di universitas mataram. Metode pengujian yaitu menggunakan destilasi uap 1999. Dari pengujian ketiga sampel hasil analisis laboratorium diperoleh yaitu sampel 1 dengan nilai $\mathrm{N}$ sebesar 0,19\% dengan kandungan amoniak sebesar 204 (mg/L), sampel 2 dengan nilai $\mathrm{N}$ sebesar 0,14 dengan kandungan amoniak sebesar 153 (mg/L), sampel 3 dengan nilai $\mathrm{N}$ sebesar 0,16\% dengan kandungan amoniak sebesar 170 (mg/L). dari ketiga sampel tersebut sampel 2 merupakan sampel yang memiliki kandungan yang sesuai dengan kebutuhan tanaman dan memiliki senyawa amoniak yang paling rendah dari ketiga sampel tersebut. Kandungan $\mathrm{N}$ pada urine sapi sangat penting untuk tumbuhan. Menurut Maretta (2016) bahwa unsur $\mathrm{N}$ merupakan komponen utama dari nukleotida, asam nukleat, protein (termasuk protein struktural dan enzim) dan klorofil. Menurut Jauhari (2008) dalam Maretta (2016) bahwa unsur N penting dalam pertumbuhan tanaman terutama dalam proses pembelahan sel dan pemanjangan sel meristem pada titik tumbuh batang tanaman. Pertumbuhan tinggi tanaman yang rendah terjadi karena ketersediaan unsur $\mathrm{N}$ yang rendah sehingga pembelahan dan pemanjangan sel jaringan meristematik pada titik tumbuh batang Kandungan $\mathrm{N}$ sebanyak $0,14 \%$ merupakan kandungan yang sesuai untuk kebutuhan tanaman.

Setelah melakukan uji lab, produk olahan dari limbah urine sapi dikemas menggunakan botol dengan volume $400 \mathrm{~mL}$. Dalam sehari urine yang dihasilkan yaitu sekitar 10 botol. Hal tersebut karena produksi urine sapi masih dalam sekala tradisional dan mengandalkan beberapa orang. limbah urine sapi dapat diaplikasikanan pada tanaman yaitu dapat dilakukan dengan mengencerkan pada air dengan perbandingan 1:10 yang artinya 1 liter pupuk cair organik diencerkan pada 10 liter air. Pupuk organik cair dapat disemprotkan 1-2 kali dalam seminggu. Produk olahan pupuk organik cair (POC) dipasarkan dikalangan para petani di sekitar desa Sepakek. Selain itu, pemasarannya dilakukan melalui media sosial.

Pembuatan produk olahan dari limbah urine sapi berfokus pada kepada masyarakat Masyarakat desa sepakek diberikan penyuluhan atau sosialisasi yang bertujuan membangun kesadaran masyarakat bagaimana arti penting pengolahan limbah yang awalnya dibuang percuma kemudian menjadi suatu produk olahan yang memiliki nilai jual yang tinggi. Dalam penyuluhan tersebut kelompok yang disasar yaitu kelompok tani dari masing-masing dusun di desa Sepakek, kelompok wanita tani (KWT) barokah yang ada di dusun Kelana. Penuyuluhan atau sosialisasi dilakukan oleh mahasiswa kuliah kerja nyata $(\mathrm{KKN})$ desa Sepakek. Pelaksaan kegiatan sosialisasi dilakukan di aula BSI (Bank Sampah Induk) Desa Sepakek, yang dihadiri oleh Kepala Desa Sepakek, Ketua Bank sampah Lestari, perwakilan ketua kelompok tani beserta kader dari kedua kelompok tani dan beberapa masyarakat desa Sepakek. Dalam kegiatan ini Tim pelaksana telah mensosialisasikan tujuan kegiatan sosialisasi, target dan luaran yang akan dicapai, dan juga telah menjelaskan pemanfaatan limbah ternak sapi yang dapat diolah dengan teknik sederhana menjadi pupuk organik cair. Dijelaskan juga beberapa keuntungan dan kemudahan dalam pemanfaatan/penggunaan pupuk organik. Hasil yang dicapai dari tahap kegiatan sosialisasi yang telah dilakukan.

Dengan adanya kegiatan pembuatan produk olahan pupuk organik cair (POC) urine sapi dan kegiatan sosialisasi kepada masyarakat desa Sepakek diharapkan mampu mengembangkan produk tersebut sehingga kebermanfaatannya berkelanjutan serta dapat menopang prekonomian masyarakat desa Sepakek. 


\section{KESIMPULAN}

Dari kegiatan yang telah dilakukan dapat disimpulkan bahwa limbah peternakan urine sapi dapat dimanfaatkan menjadi produk olahan pupuk cair organik (POC) dengan metode fermentasi dan metode sistem aerasi sehingga dapat melestarikan lingkungan dan memperbaiki prekonomian masyarakat di Desa Sepakek.

\section{REFERENSI}

Maretta S. 2003. Sifat kimia Entisol pada sistem pertanian organik. IImu Pertanian.10 (2):63-6.

Maretta, W., Suhadi dan Agung W. 2016. Pengaruh Konsentrasi Urine Sapi Brahman (Bos taurus indicus Linn.) Terhadap Pertumbuhan Bibit Cabai Rawit (Capsicum frutescens Linn.)

Putri, H. 2017. Pengaruh Berbagai Konsentrasi Pupuk Organik Cair (POC) urin Sapi TerhadapPertumbuhan Tanaman Hijau (Amaranthus tricolor L.) . Universitas Sanata Dharma. Yogyakarta.

Rasyid, R. 2017. Kualitas Pupuk Cair (Biourine) Kelinci Yang Diproduksi Menggunakan Jenis Dekomposer Dan Lama Proses Aerasi Yang Berbeda. Skripsi. Program Studi Peternakan Fakultas Peternakan Universitas Hasanuddin Makassar. Makassar.

Rizki, K, Aslim R dan Murniati. 2014. Pengaruh Pemberian Urin Sapi Yang Difermentasi Terhadap Pertumbuhan Dan Produksi Tanaman Sawi Hijau (Brassica Rafa). Jom Faperta. 1(2) : 1-11.

Rohani St. 2016. Model Pemanfaatan Urine Sapi Sebagai Pupuk Organik Cair Kecamatan Liburen Kabupaten Bone. Jurnal Panrita Abdi. 1(1):11-15.

Siburian T. 2006. Analisis Biologi Pangan. PT. Raja GraFindo Persada. Jakarta, 5-50.

Wahyono S., 2011. Pengolahan Sampah Organik dan Aspek Sanitasi. Jurnal Teknologi Lingkungan. 2(2) : 113-118.

Waresfram. 2010. Aplikasi pupuk organik cair terhadap pertumbuhan dan produksi tanaman sawi. Jurnal Agrisistem. 7 (1): $27-34$. 